\title{
THE NORMANS IN EUROPE
}

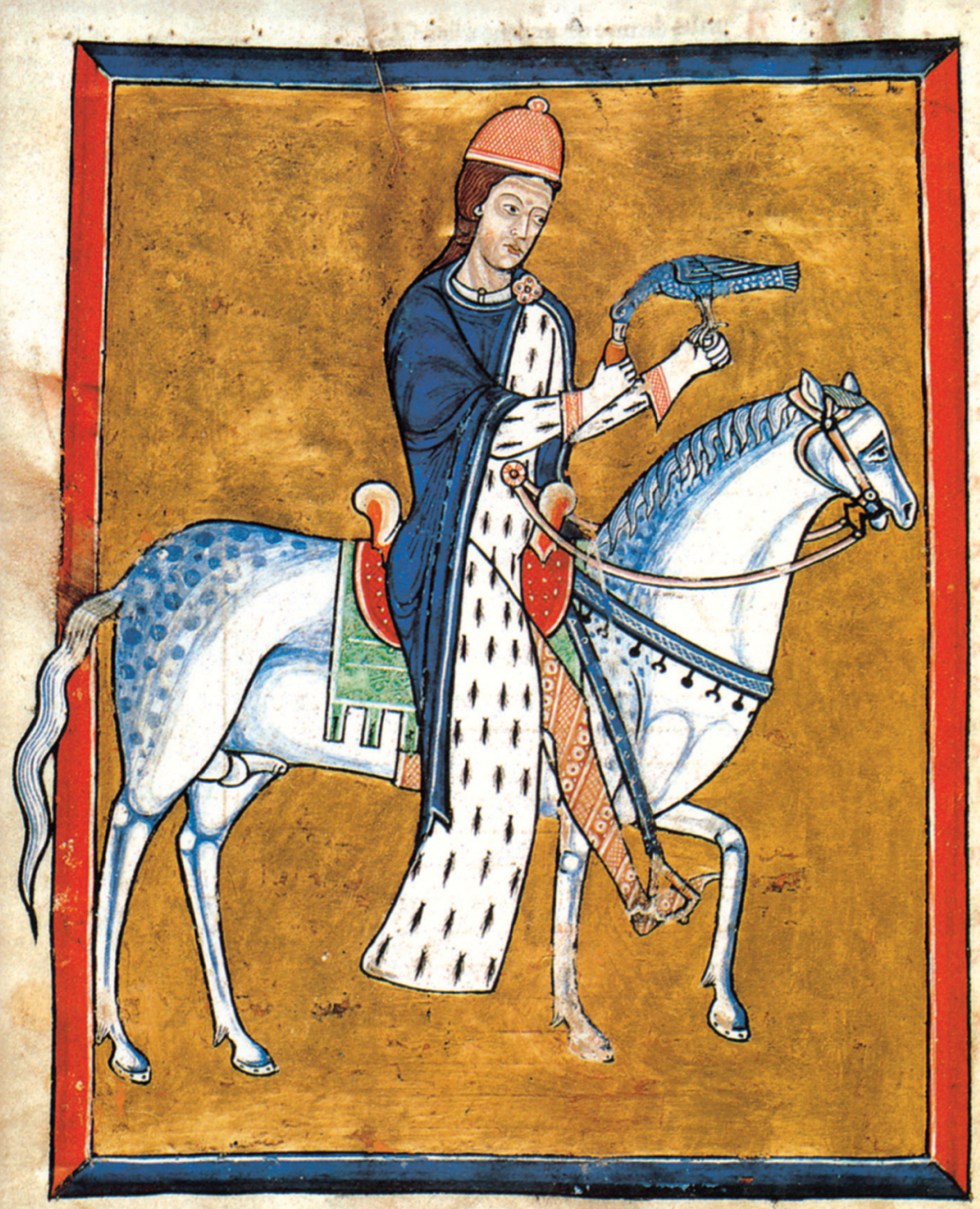

Translated and edited by Elisabeth van Houts 


\section{THE NORMANS IN EUROPE}

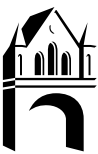

MANCHESTER UNIVERSITY PRESS 
Manchester Medieval Sources Series

series advisers Rosemary Horrox and Janet L. Nelson

This series aims to meet a growing need amongst students and teachers of medieval history for translations of key sources that are directly usable in students' own work. It provides texts central to medieval studies courses and focuses upon the diverse cultural and social as well as political conditions that affected the functioning of all levels of medieval society. The basic premise of the series is that translations must be accompanied by sufficient introductory and explanatory material, and each volume, therefore, includes a comprehensive guide to the sources' interpretation, including discussion of critical linguistic problems and an assessment of the most recent research on the topics being covered.

already published in the series

J. A. Boyle Genghis Khan: history of the world conquerer

John Edwards The Jews in Western Europe, 1400-1600

Trevor Dean The towns of Italy in the later Middle Ages

Richard Fletcher and Simon Barton The World of El Cid

Paul Fouracre and Richard A. Gerberding Late Merovingian France

Chris Given-Wilson Chronicles of the Revolution, 1397-1400: the reign of Richard II

P. J. P. Goldberg Women in England, c. 1275-1525

Janet Hamilton and Bernard Hamilton Christian dualist heresies in the Byzantine world c. $650-$ c. 1450

Rosemary Horrox The Black Death

Helen Jewell Women in medieval England

Graham A. Loud and Thomas Wiedemann The history of the tyrants of Sicily by 'Hugo Falcandus', 1153-69

Janet L. Nelson The Annals of St-Bertin: ninth-century histories, volume I

Timothy Reuter The Annals of Fulda: ninth-century histories, volume II

R. N. Swanson Catholic England: faith, religion and observance before the Reformation

Elizabeth van Houts The Normans in Europe

Jennifer Ward Women of the English nobility and gentry, 1066-1500

forthcoming titles in the series will include

Mark Bailey English manorial records, c. 1180-1520.

Ross Balzaretti North Italian histories, AD 800-1100

Brenda Bolton Innocent III

Judith Jesch and Bridget Morris The Viking Age

Simon Lloyd The impact of the crusades: the experience of England, 1095-1274

Alison McHardy The early reign of Richard II

Edward Powell and Anthony Musson Crime, law and society in late medieval England

Ian Robinson The Pontificate of Gregory VII

Richard Smith Sources for the population history of England, 1000-1540 


\section{THE NORMANS IN EUROPE}

edited and translated by Elisabeth van Houts

Manchester University Press

Manchester 
Copyright (C) Elisabeth van Houts 2000

While copyright as a whole and of all editorial matter is vested in Elisabeth van Houts, copyright of all other material belongs to the respective authors, translators and institutions as acknowledged, and no editorial or documentary material may be reproduced wholly or in part without the express permission in writing of both author and publisher.

Published by Manchester University Press

Altrincham Street, Manchester Mi 7JA, UK

www.manchesteruniversitypress.co.uk

British Library Cataloguing-in-Publication Data

A catalogue record for this book is available from the British Library

Library of Congress Cataloging-in-Publication Data applied for

ISBN 0719047501 hardback

o 71904751 X paperback

First published 2000

$\begin{array}{llllllllllllllllll}07 & 06 & 05 & 04 & 03 & 02 & 01 & 00 & 10 & 9 & 8 & 7 & 6 & 5 & 4 & 3 & 2 & 1\end{array}$

The publisher has no responsibility for the persistence or accuracy of URLs for any external or third-party internet websites referred to in this book, and does not guarantee that any content on such websites is, or will remain, accurate or appropriate.

Typeset in Monotype Bell

by Koinonia Ltd, Manchester 